\title{
Pedagogical Practices Employed in Teaching and Learning Speaking Skills at Taif University
}

\author{
Abdul Fattah Soomro ${ }^{1}$ \\ ${ }^{1}$ English Language Centre, Deanship of Supportive Studies, Taif University, Saudi Arabia \\ Correspondence: Abdul Fattah Soomro, English Language Centre, Deanship of Supportive Studies, Taif \\ University, PO Box 888, Taif 21974, Kingdom of Saudi Arabia. E-mail: a.nizamuddin@tu.edu.sa
}

Received: February 9, 2018 Accepted: April 26, 2018 Online Published: May 2, 2018

doi:10.5539/ijel.v8n4p273 URL: https://doi.org/10.5539/ijel.v8n4p273

\begin{abstract}
The aim of instructing speaking skills is to help students develop better oral communication. That is possible if teachers employ better techniques to enhance the use of English in the class and motivate their learners to utilize important strategies for practicing speaking skills. The current study investigates pedagogical practices in use by English professionals to teach speaking skills to their students, and strategies and approaches applied by leaners to improve their speaking skills. Questionnaire survey was conducted by recruiting 184 male and female undergraduate students from different streams at Taif University. The data was analyzed through SPSS and presented with the help of descriptive tables. The results of this study reveal that teachers moderately employed important techniques and strategies in their teaching. Among the strategies and techniques which were not frequently employed by English professionals were: role-play, group work, pair discussion, picture description, dialogue, debating, and storytelling. Students also lacked in utilizing important strategies which hinder their progress in developing better speaking skills. The attitude of learners towards learning a foreign language was negatively affected by the level of difficulties faced by them. The study concluded that teachers' role is very important to develop a favorable learning environment and involve students to practice English through various useful techniques and strategies necessary for the development of speaking skills.
\end{abstract}

Keywords: pedagogical practices, strategies, techniques, attitude, difficulties and learners' experience of speaking skills

\section{Background}

English is an international language; it can be utilized to communicate with people either native or non-native ones. However, it has more application in academic sector because all students in the universities require English to study and search information in this language. That is why a number of universities in the world would have to put English as a necessary academic requirement. At higher education stage English language is mostly incorporated as medium of instruction (Murray \& Christison, 2010). It is most essential to have fluency in communication when speaking English as foreign language (EFL) or second language (ESL) when it comes to oral communication. Moreover, it is complex phenomena to communicate but simultaneously most significant to make progress in various fields (Al-Sibai, 2004, p. 3).

The aim of instructing speaking skills is to make students' oral commination better. That is why the main objective of teaching activities in the class should be enhancing language use of students (Haozhang, 1997). Previously, the oral skills were ignored deliberately with a misconception that they will develop naturally later on and was believed that the cognitive skills in writing activities will generate oral skills (Chaney, 1998). Further, Ur (1996) believes that among all four skills (listening, speaking, reading, and writing) speaking is the most important one because the persons who know a language are called as speakers of that language. It makes the sense that it is more important to use a language then just to know about that because it has no value if you have plethora of knowledge regarding a language but you are unable to use it (Scrivener, 2005, p. 146).

\subsection{Learning Environment for Teaching Speaking}

To make language learning, the three pre-requisite needs be met and they are: exposure, opportunities to use language, instruction and motivation. Learners need a space to elaborate what they feel, think and experiment in an environment helping one with no fear or threat (Willis, 1996, p. 7). The second language research reveals a 
fact that when conscious endeavors are taken to learn, the less progress is seen. On the contrary, it occurs spontaneously, the subconscious faculties of mind become active when learners are busy in communication in target language. The subconscious factors need a variety of activities, where the communication of meaning is focused by the learners not merely the language (Littlewood, 1984). Further, Harmer (1982) also maintain that when it comes to communication students focus be based on what they are saying rather than on form. As per Ellis (2003), this could be performed by learners by engaging them in two sort of communicative tasks: unfocused and focused communicative tasks. These both tasks engage learners practically instead of merely displaying language. The language proficiency is improved through communication. The communication also helps the learners to integrate the secluded structures into a creative one in order to get meaning (Littlewood, 1984, p. 91).

\subsection{Factors that Cause Speaking Difficulties to EFL Learners}

According to Zhang (2009), among all the skills of language, mastering speaking skill is the most difficult one. As per the thoughts of Ur (1996), there are multiple factors that cause difficulty in speaking, as:

1) Inhibition: Students feel shyness, fear to commit mistakes and fear criticism.

2) Nothing to say: Students lack any reason to say something.

3) Low or uneven participation: A single candidate could talk at a time, however, some learners even dominate and on contrary some speak less and others not speak at all.

4) Mother tongue use: Learners with same mother tongue usually talk in it; it is because they feel convenient and have less chance to be exposed if they communicate in their mother tongues.

In this regard, Rababa' $h$ (2005) highlighted that there are multiple factors that cause hindrance to EFL learners in speaking English. The factors include curriculum, environment and learners' own attributes. For instance, a lot of leaners feel they have less vocabulary to make the meaning clear and in result of this they could not carry on interaction. Moreover, Communication competence, not keeping interaction and inadequate strategic competence could also be the reasons.

Motivation is also a factor which some learners lack when they have to talk. They could not find a genuine need to speak or learn English. Actually, the motivation reveals how much efforts a learner takes, it makes one decide whether the learners achieve goals or not and how much energy one dedicates to it (Littlewood, 1984, p. 53). The progress in communication skills could occur provided that learners possess motivation and connect with the people around (Littlewood, 1981). Further, the teaching techniques also matter in this regard if they are inadequate and do not stress on speaking skills then result is poor communication skills. Similarly, the vocabulary is instructed in isolation and speaking skills are not practiced by the class teachers in the classes because of less availability of classes as compared to the number of teachers.

Moreover, rest of the subjects is in Arabic, and English is viewed as an academic module only, which shows that exposure to English is insufficient. No environment for the use of target language could be another problem and thus, results in less real situation environment. Less exposure to the learners to contribute in the discourse could be another reason to speaking difficulties. Students require to develop knowledge and skills to be a part of discourse and even to learn discourse expertise (Cameron, 2001, p. 36). Furthermore, the situation in which language is properly learnt when the concentration of learner is focused on understanding, doing something with the language, and not in the time when their concentration is just on linguistic characteristics (Kumaravadivelu, 2003 , p. 27). It is much appreciating to learn that the researchers recognize the fact that the learners could better learn by developing their own strategies to learn the language by becoming independent learners (Nakatani, 2010).

Littlewood (1981) maintains that L1 is also used for class management by some teachers. This could be one of the other reasons to promote difficulties in speaking English. This means with the usage of L1, the valuable time is compromised to learn foreign language. Moreover, it gives less value to the target language to be used as a source of communication (Al-Busaidi, 1998). The debate about the use of L1 for teaching English in the EFL context of Arab nations have divergent opinions. Palmer et al. (2007) disagreeing with Abdo \& Breen (2010) suggests that Arabic should be allowed to be used at school to help students learn English language skills. In addition to using Arabic, Palmer et al. (ibid) recommends that text books must be appropriate and accommodative to the culture and linguistic needs of Arab students. Melvin \& Stout (1987 cited in Akasha, 2013) said that "Authentic texts give students direct access to the culture and help them use the new language authentically themselves, to communicate meaning in meaningful situations rather than for demonstrating knowledge of a grammar point or a lexical item" (p. 44). Dong (2004) agrees with idea of Melvin \& Stout (1987) 
and Palmer et al. (2007) to include authentic text. Arabi language and Arabi literature should be introduced to increase the participation and interest of students in the classroom activities (Wingfield \& Karaman, 2001). Teachers are suggested to adjust curriculum to include leaners' culture and their life style to facilitate Arabic-speaking ESL students (Santos \& Suleiman, 1993). Gilmore (2007) defines authenticity in a broader way by including different situations: the text, cultural and social situations and the participants.

Fluency in speaking skill is considered as a main goal of all leaners. However, the majority of leaners do not get successful in achieving this. There may be number of reasons. May be, the current practices of teaching speaking skills are not effective. May be, teachers are not good enough to transfer such skills among the learners. May be, leaners are not serious in making efforts to develop such skills. Curriculum may be faulty. As such there is no much literature available to guide us to know which factors are really responsible for poor speaking skills among the learners. The lack of research about leaners' experience of speaking skills is a main problem. The current study aims to fill in this gap by exploring the impact of social, cultural and motivational factors on the development of speaking skills among the leaners. The current study also evaluates the significance of a number of factors for the development of speaking skills such as techniques and strategies in use by both the teachers and learners, learners' attitude and difficulties faced in developing speaking skills and It also seeks to investigate the impact of social relations of power in creating the possible opportunities for language learners to speak and the nature of conditions/environment in which language learners at TUELC try to speak, pedagogic practices in use at TUELC (Norton \& Toohey, 2001) and level of seriousness by students in making personal effort for using the target language (Norton, 1995, 1997). The current study aims to contribute to the existing literature on the topic as well as inform the pedagogic practices to be used by teachers to teach speaking skills at TUELC answering the following questions:

\subsection{Research Questions}

1) What techniques and strategies do teachers use in teaching speaking skills?

2) What strategies do learners use in in the development of their speaking skills?

3) What challenges and difficulties do leaners face in developing their speaking skills?

4) What is the effect of pedagogic practices on the attitude of learners towards developing speaking skills?

\section{Research Design}

The quantitative approach is adopted by employing questionnaire survey to collect the data. The questionnaire was adopted from the study conducted by Chot (2015). However, the researcher adapted it in the light of contextual realities after reviewing a vast literature related to the topic. Two hundred fifty questionnaire were randomly distributed among male and female students from different faculties studying in Science, Humanities, Medicine, Business and Engineering. Equal number of questionnaire (125) were distributed among male and female campuses. Female students returned 85 questionnaires with response rate of $68 \%$ compared to $79 \%$ of response rate from the male students. In total, 184 questionnaires out of 250 were returned with $74 \%$ response rate. The response rate of the participant- students from different faculties had much different from one another. $\% 0$ questionnaires were sent among each of five faculties. The researcher received 40 questionnaires with $80 \%$ response rate from the students of Humanities. Science students returned 38 with $76 \%$ response rate. Medicine students returned 42 with maximum response rate of $82 \%$ compared to all other faculties. The response rate of Engineering students was the lowest with $60 \%$ and only 30 questionnaires were returned. 34 students from Business faculty participated in the survey with $68 \%$ response rate. The response rate of students in second semester was almost $75 \%$ compared to the response rate of $68 \%$ from the first semester students. Over all, there was a good response rate from different stratum of the population resulting in a valid representative sample for this study. The data collected through the questionnaire was analyzed using SPSS. The results are presented through descriptive tables

\subsection{Reliability}

The vast body of literature highlights the significance of trustworthiness, validity, authenticity, reliability, and generalizability. There is overlapping between these terms as they are quite related with each other. In this regard, Cohen et al. (2007) maintains that it's important for a study (qualitative or quantitative in nature) to be valid and reliable. Thus, the reliability was measured by Cronbach's alpha. The statistics of the reliability for all the sections in the questionnaire are given in Table 1: 
Table 1. Reliability statistics of techniques used by the teacher

\begin{tabular}{|c|c|c|}
\hline Cronbach's Alpha & Cronbach's Alpha Based on Standardized Items & $\mathrm{N}$ of Items \\
\hline .807 & .811 & 13 \\
\hline \multicolumn{3}{|c|}{ Reliability Statistics of Strategies used by the Teacher } \\
\hline Cronbach's Alpha & Cronbach's Alpha Based on Standardized Items & $\mathrm{N}$ of Items \\
\hline .726 & .707 & 6 \\
\hline \multicolumn{3}{|c|}{ Reliability Statistics of Strategies used by students } \\
\hline Cronbach's Alpha & Cronbach's Alpha Based on Standardized Items & $\mathrm{N}$ of Items \\
\hline .779 & .881 & 5 \\
\hline \multicolumn{3}{|c|}{ Reliability Statistics of Learners' attitude } \\
\hline Cronbach's Alpha & Cronbach's Alpha Based on Standardized Items & $\mathrm{N}$ of Items \\
\hline .861 & .828 & 5 \\
\hline \multicolumn{3}{|c|}{ Reliability Statistics of Students' difficulties } \\
\hline Cronbach’s Alpha & Cronbach's Alpha Based on Standardized Items & $\mathrm{N}$ of Items \\
\hline .770 & .771 & 9 \\
\hline \multicolumn{3}{|c|}{ Reliability Statistics of Learning-Environment related Factors } \\
\hline Cronbach's Alpha & Cronbach's Alpha Based on Standardized Items & $\mathrm{N}$ of Items \\
\hline .926 & .959 & 4 \\
\hline
\end{tabular}

The range of alpha scale for all items in all the sections as shown in the table is above 0.8 , which indicates high reliability for these sections too. In this way, reliability of the constructs is .80 (i.e., $80 \%$ ) which is well above than the required value, i.e., 0.60 (Cronbach, 1951). So results of this study are reliable.

\section{Results and Discussion}

\subsection{Teachers-Related Factors}

There are two sections in the first part of the questionnaire titled as Teachers-related Factors. The first part inquires about the techniques used by the teachers and second part investigates about the strategies used by the teachers.

Table 2. Techniques used by the teacher

\begin{tabular}{|c|c|c|c|c|c|}
\hline \multicolumn{6}{|l|}{ Descriptive Statistics } \\
\hline & $\mathrm{N}$ & Minimum & Maximum & Mean & Std. Deviation \\
\hline Questioning and answering & 184 & 1 & 5 & 1.91 & .883 \\
\hline Pairs or group discussion & 184 & 1 & 4 & 2.31 & .885 \\
\hline Conversations or dialogues & 184 & 1 & 5 & 2.68 & 1.107 \\
\hline Role play and drama & 184 & 1 & 5 & 3.02 & 1.252 \\
\hline Picture description & 184 & 1 & 5 & 2.84 & 1.273 \\
\hline Panel discussion and debating & 184 & 1 & 5 & 2.73 & 1.301 \\
\hline Storytelling & 184 & 1 & 5 & 2.49 & 1.071 \\
\hline Peers interview & 184 & 1 & 5 & 2.43 & .995 \\
\hline Giving instruction on given topics & 184 & 1 & 5 & 2.35 & 1.035 \\
\hline $\begin{array}{l}\text { Listening to the records on the radio or video and present the report } \\
\text { back to the class }\end{array}$ & 184 & 1 & 5 & 2.50 & 1.056 \\
\hline Daily or weekly individual/ group presentation on completed project & 184 & 1 & 5 & 2.62 & 1.275 \\
\hline Project-based activities (performing certain tasks to learn speaking?) & 184 & 1 & 5 & 2.65 & 1.214 \\
\hline $\begin{array}{l}\text { Monologues (in which each of you is asked to prepare to talk about a } \\
\text { hobby or personal interest for three or five minutes) }\end{array}$ & 184 & 1 & 5 & 2.47 & 1.280 \\
\hline Valid N (list wise) & 184 & & & & \\
\hline
\end{tabular}

Overall mean value of this section consisting of 13 items is above the neutral score of 2.5 indicating that teachers do not maximize the use of techniques for teaching speaking skills. The mean value for each of thirteen questions is either near or above 2.5 which suggests that teachers moderately use techniques in their practice of teaching speaking skills. Looking at the individual mean as shown in the above table, techniques used by the teacher in classroom and the responses of the learners. The descriptive statistics reveal that the most common technique used by teachers is "questioning and answering" followed by "pairs or group discussion" and "giving instruction on given topics". The least used techniques are "picture description" and "conversation or dialogues project". It is noticed that more frequent technique used by teacher was "Questioning and answering" with mean 
1.9 and $\mathrm{SD} \pm .883$ and least techniques used by teachers was "Role play and drama" with mean 3.02 and $\mathrm{SD} \pm 1.25$.

Table 3. Strategies used by the teacher

\begin{tabular}{llllll}
\hline Descriptive Statistics & & & & \\
& $\mathrm{N}$ & Minimum & Maximum & Mean & Std. Deviation \\
\hline allows me to ask for feedback (or mistakes correction). & 184 & 1 & 5 & 2.35 & 1.182 \\
presents pronunciation points that may boost my speaking & 184 & 1 & 5 & 2.45 & 1.168 \\
fluency and confidence in learning English speaking skills. & & & & & \\
Has good speaking activities design. & 184 & 1 & 5 & 2.78 & 1.081 \\
uses learners-centered approach. & 184 & 1 & 5 & 2.68 & 1.306 \\
gives enough time to various speaking exercises. & 184 & 1 & 5 & 2.68 & 1.111 \\
scolds student for not speaking correctly(or with poor accent). & 184 & 1 & 3 & 1.82 & .705 \\
Valid N (listwise) & 184 & & & & \\
\hline
\end{tabular}

Overall mean of all the six items in this construct is 2.46 with variance of 1.208 which states that the teachers do not frequently employ these strategies in their teaching of speaking skills. The mean value for three items; "has good speaking activities design", "uses learners-centered approach", "gives enough time to various speaking exercises" is above 2.50 which indicates that students do not agree that teachers use them in the class. The teachers use only a couple of strategies such as allows students to ask for feedback (or mistakes correction) and help them in pronunciation. It is noticed that more frequent technique used by teacher as perceived by the student-participants is "scolds student for not speaking correctly (or with poor accent)" with mean=1.82 SD \pm .705 . The least technique used by teachers was "has good speaking activities design." with mean 2.78 and $\mathrm{SD} \pm 1.08$.

\subsection{Students-Related Factors}

Part (3) of the questionnaire investigates students-related factors. It has three sections; strategies used by the learners, their attitude and difficulties in developing speaking skills.

Table 4. Strategies used by students to learn English speaking skills

\begin{tabular}{|c|c|c|c|c|c|}
\hline \multicolumn{6}{|l|}{ Descriptive Statistics } \\
\hline & $\mathrm{N}$ & Minimum & Maximum & Mean & Std. Deviation \\
\hline I speak in English inside the classroom. & 184 & 1 & 5 & 2.83 & 1.106 \\
\hline I can make a phone conversation in English. & 184 & 1 & 5 & 2.49 & 1.040 \\
\hline $\begin{array}{l}\text { I actively participate in the class and like to present my group's ideas } \\
\text { to the whole class in English. }\end{array}$ & 184 & 1 & 5 & 2.53 & 1.035 \\
\hline $\begin{array}{l}\text { I evaluate my own weaknesses and strengths in learning English } \\
\text { speaking skills. }\end{array}$ & 184 & 1 & 5 & 2.51 & 1.233 \\
\hline $\begin{array}{l}\text { I watch and listen to English TV \& radio Programs (BBC, CNN, } \\
\text { hard talks, debating...etc.) as a model for English speaking skills } \\
\text { and to help me build my English listening comprehension. }\end{array}$ & 184 & 1 & 5 & 2.88 & 1.070 \\
\hline Valid N (list wise) & 184 & & & & \\
\hline
\end{tabular}

This construct consists of 5 questions. Average mean of five question items in this construct is 2.64 with variance of .037 which indicates that learners do not usually utilize these strategies. The descriptive table shows that there is only one strategy out of 5 which has mean value below 2.5 with rating scale from 1-5 where 1 stands for strongly agree and 5 for strongly disagree. It means students use only one strategy "make phone conversation in English" with mean value of 2.49 which is just below the neutral score of 2.50. Except this, all other items have mean value above 2.50 indicating that students fail to utilize these strategies while developing their speaking skills. On the whole, the results suggest that students rarely use these strategies such as "evaluate their own weaknesses and strengths", "actively participate in the class", "watch and listen to English TV programs". 
Table 5. Learners' attitude towards learning English speaking skills

\begin{tabular}{llllll}
\hline Descriptive Statistics & N & Minimum & Maximum & Mean & Std. Deviation \\
\hline $\begin{array}{l}\text { I have confidence in English speaking. } \\
\text { I am motivated in learning English speaking because I see }\end{array}$ & 184 & 1 & 5 & 2.69 & 1.115 \\
that it is advantageous. & & & 5 & 2.87 & 1.185 \\
$\begin{array}{l}\text { I do not have resentment towards teacher who mistreat or } \\
\text { insult me. }\end{array}$ & 184 & 1 & 5 & 2.43 & 1.139 \\
$\begin{array}{l}\text { I do not prefer to speak in mother tongue. } \\
\text { I positive attitude towards the culture of native speakers of }\end{array}$ & 184 & 1 & 5 & 2.71 & 1.067 \\
$\quad \begin{array}{l}\text { English. } \\
\text { Valid N (list wise) }\end{array}$ & 184 & 5 & 2.80 & .775 \\
\end{tabular}

This construct consisted of 5 questions. Average mean of all the question items from this construct was 2. With variance of .095 . Since the mean value is higher than the neutral value, it suggests that student-participants didn't show the positive attitude to learning this skill. Students don't feel motivated and lack of confidence is one of those factors that affect negatively on their attitude towards learning speaking skills. In addition, they prefer using their mother tongue to English while they are in the class and outside it. Student-participants also displayed negative attitude to the culture of the target language (English). The negative attitude towards learning speaking skills may be attributed to the teaching approach adopted by the teachers and learning approach practiced by the students of Taif University.

Table 6. Students' difficulties in learning English speaking skills

\begin{tabular}{|c|c|c|c|c|c|}
\hline \multicolumn{6}{|l|}{ Descriptive Statistics } \\
\hline & $\mathrm{N}$ & Minimum & Maximum & Mean & Std. Deviation \\
\hline $\begin{array}{l}\text { Find it difficult to listen and comprehend what other person is } \\
\text { saying in English }\end{array}$ & 184 & 1 & 5 & 2.47 & 1.101 \\
\hline $\begin{array}{l}\text { haven't a good knowledge of English grammar that led me } \\
\text { construct errors free sentences when speaking }\end{array}$ & 184 & 1 & 5 & 2.80 & 1.119 \\
\hline $\begin{array}{l}\text { haven't a good knowledge of English vocabulary that can let me } \\
\text { easily express my ideas when speaking }\end{array}$ & 184 & 1 & 5 & 2.72 & 1.084 \\
\hline $\begin{array}{l}\text { pause a lot or say "ah" or "um" many times when I speak in } \\
\text { English? }\end{array}$ & 184 & 1 & 5 & 2.61 & 1.080 \\
\hline $\begin{array}{l}\text { When speaking in English, first construct my message in my } \\
\text { mother tongue and then translate it into English word-by-word }\end{array}$ & 184 & 1 & 5 & 2.70 & 1.264 \\
\hline worried about making mistakes. & 184 & 1 & 5 & 2.66 & 1.064 \\
\hline fearful of criticism or losing face. & 184 & 1 & 5 & 2.52 & 1.101 \\
\hline feeling pressure to perform well & 184 & 1 & 5 & 2.48 & 1.155 \\
\hline not given plenty of time to perform a speaking task in the class. & 184 & 1 & 5 & 2.47 & 1.237 \\
\hline Valid N (listwise) & 184 & & & & \\
\hline
\end{tabular}

As shown in the table above, there are nine question items inquiring student-participants about the difficulties they face in developing their speaking skills. Average mean of all the question items from this construct was 2.6 with variance of .016. This suggests that the level of difficulties faced by student-participants is very challenging. The respondents reported that they feel under pressure for doing better performance in the class without committing mistakes in practicing speaking skills. It is noticed by looking at the table that students are not given enough time to perform better in a classroom speaking task. Another frequent difficulty as faced is learner's lack of knowledge in grammar leads them to making mistakes when they try to construct a correct sentence in spoken English. In addition to having difficulty in performing spoken skills, the students face problem in comprehension and understanding spoken language of other people. It is noticed that less frequent difficulty faced is that they have "not given plenty of time to perform a speaking task in the class" with mean 2.47 and $\mathrm{SD} \pm 1.23$ and more frequent difficulty faced by the learners is that they "haven't a good knowledge of English grammar that led me (them) construct errors free sentences when speaking" with mean 2.80 and $\mathrm{SD} \pm 1.11$. 


\subsection{Learning Environment Related Factors}

Table 7. Learning environment related factors

\begin{tabular}{llllll}
\hline Descriptive Statistics & $\mathrm{N}$ & Minimum & Maximum & Mean & Std. Deviation \\
\hline $\begin{array}{l}\text { The classroom setting facilitates students in practicing } \\
\text { speaking skills. }\end{array}$ & 184 & 1 & 5 & 2.58 & 1.157 \\
$\begin{array}{l}\text { The classroom is equipped with modern learning resources to } \\
\text { help students in speaking skills. }\end{array}$ & 184 & 1 & 5 & 2.74 & 1.001 \\
$\begin{array}{l}\text { The students have access to audio and video resources } \\
\text { available in the Centre. }\end{array}$ & 184 & 1 & 5 & 3.20 & .945 \\
$\begin{array}{l}\text { The students practice speaking skills in a language lab. } \\
\text { Valid N (list wise) }\end{array}$ & 183 & 1 & 5 & 3.18 & 1.188 \\
\end{tabular}

This construct as shown in the table has only 4 questions. Average mean of four question items in this construct is 2.92 with variance of .095 , which shows that learners do not have access to modern learning resources. In addition, the classroom setting seems not to be facilitating the practicing of speaking skills. The mean value of all the question items is above the neutral value of 2.50. This indicates that learning environment related factors negatively affect the development of speaking skills among the learners. It is observed that less affecting learning environment related factor is "the classroom setting facilitates students in practicing speaking skills" with mean 2.58 and $\mathrm{SD} \pm 1.15$ and more affecting learning- Environment related factor is "the students practice speaking skills in a language lab." with mean 3.18 and $\mathrm{SD} \pm 1.18$.

\section{Conclusion and Recommendations}

On the basis of findings, it could be inferred that teachers need to work hard for playing very effective role in developing students' speaking skills. The results show that teachers moderately employed important techniques and strategies in their teaching in order to encourage students so that they could improve speaking in English. Among the strategies and techniques which were not frequently employed by English professionals were: role-play, group pair discussion, picture description, dialogue, debating, and storytelling. Teachers, though, designed good speaking activities but could not spare sufficient time to practice these techniques and strategies. Learners-centered approach wasn't frequently applied by the teachers while teaching speaking skills. In fact, English teachers are supposed to design such speaking activities which may pave the path or open up the opportunities for students so that they use the language in situations similar to real-life communication. In contrast, the study revealed that teachers did not frequently involved their students in project-based, monologues and other speaking activities.

Languages are acquired through practice in and outside the class. Practicing a foreign language outside the classroom is not an easy task. Learners need to be convinced of the importance of using English in, as well as outside the class. Learners must be made aware of the significance as well as opportunities for practicing English in real life situations. However, the results revealed a different scenario that students practice little English only while they are inside the classroom. Limiting the practice of English just inside the classroom is another factor hinders the progress of learners in learning speaking English. Instead of becoming autonomous learners, the study findings showed that students didn't actively participate in the class discussion; they were not ready to assess their strengths and weakness in learning speaking skills. This indicates lack of motivation among learners which agree with Littlewood (1981) that progress in communication skills could occur provided that learners possess motivation and connect with the people around them. The finding also showed Students don't feel motivated and displayed lack of confidence. These are some of the factors that affect negatively on their attitude towards learning speaking skills. These results are consistent with study conducted by (Rababa'h, 2005) that there are multiple factors that cause hindrance to EFL learners in speaking English. The factors include, curriculum, environment and learners own attributes. For instant, a lot of leaners feel they have less vocabulary to make the meaning clear and in result of this they could not carry on interaction.

The attitude of learners towards learning a foreign might have been affected by the level of difficulties faced by student-participants. The respondents reported that they feel under pressure for doing better performance in the class without committing mistakes in practicing speaking skills. These findings correspond with the study by Zhang (2009) on the learners' inhibition that students feel shyness; undergo fear of committing mistakes and facing criticism. In addition to this, findings showed that students prefer to use mother tongue and has not a 
positive attitude towards target culture. These results also correspond with the study by Zhang (2009) that learners with same mother tongue usually talk in it, it is because they feel convenient and have less chance to be exposed if they communicate in their mother tongues. In addition to having difficulty in performing spoken skills, some students face problem in comprehension and understanding spoken language of other people. Apart from such difficulties, the results revealed that state of the facilities and classroom setting were not ideal to provide frequent opportunities for learners to practice English.

\subsection{Recommendations}

The results confirm that teachers do play their role; however, they are suggested to develop favorable learning environment by involving students to practice English through various useful techniques and strategies such as dialogues, picture description, role play, storytelling, debating and peers interview. Well planned lesson on speaking always encourages the learners, so they must work harder to plan designing such speaking lesson. Teachers may double their efforts while playing their role in supervising learners' English speaking learning.

Teachers are suggested to change their role according to the needs of learners: psychological, academic and emotional. They should not discourage learners by scolding any learner who makes mistake in speaking English correctly. Teachers are suggested to design good speaking activities and utilize them well to evoke learners' interest to actively participate and willingly practice speaking skills.

Students should be encouraged to adopt better strategies and participate actively in the class such as students must be convinced to ask and answer questions. They must be involved in group and pair discussions, giving information and offering advice, sharing opinion, narrating stories, performing in language room games. Students should also be motivated to speak English outside the classroom by communicating with people around them in English. They must be prepared to use the language in the real life by taking risks and getting themselves exposed to the real situations

Special measures may be taken by the administration and teachers to attend to the difficulties faced by the students in developing speaking English. Proper advice and guidance be offered to the individual students by giving more time to discuss their problems in both classrooms and offices. Teachers may help students develop as autonomous learners by motivating and encouraging them to work harder and take personal initiatives to develop speaking through practice outside the classroom.

More research studies need to be conducted investigating the impact of various factors on the development of speaking skills in English in the EFL context of Saudi Arabia.

\section{References}

Abdo, I. B., \& Breen, G. (2010). Teaching EFL to Jordanian students: New strategies for enhancing English acquisition in a distinct Middle Eastern student population. Creative Education, 1(1), 39-50. https://doi.org/10.4236/ce.2010.11007

Akasha, O. (2013). Exploring the Challenges Facing Arabic-Speaking ESL Students \& Teachers in Middle School. Journal of ELT and Applied Linguistics (JELTAL), 1(1), 12-31.

Al-Busaidi, S. (1998). An investigation of teachers' and students' attitudes towards the use of mother tongue in the English foreign language classrooms in Oman (Unpublished master's thesis). TEFL Centre for Applies Language Studies. University of Reading.

Al-Sibai, D. (2004). Promoting oral Fluency of Second Language Learners: Educational Linguistics Department of English, King Saud University.

Chaney, A. (1998). Teaching oral communication in grades k-8. USA. A Viacom company.

Chot, P. (2015). Factors Affecting Students' Learning English Speaking Skills: A Case of second year students of English Department in Gambella College of Teachers Education (MA dissertation, AddisAbaba University).

Cohen, L., Manion, L., \& Morrison, K. (2011). Surveys, longitudinal, cross-sectional and trend studies. Research Methods in Education (7th ed., pp. 261-264). Abingdon: Routledge.

Cronbach, L. J. (1951). Coefficient alpha and the internal structure of tests. Psychometrika, 16(3), 297-334. https://doi.org/10.1007/BF02310555

Ellis, R. (2003). Task-based language learning and teaching. Oxford: Oxford University Press.

Gilmore, A. (2007). Authentic materials and authenticity in foreign language learning. Language Teaching, 40(2), 97-118. https://doi.org/10.1017/S0261444807004144 
Haozhang, X. (1997). Tape Recorders, Role Plays, and Turn-Taking in Large EFL Listening and Speaking Classes. Forum, 35(3), 3. Retrieved from http://e.usia.gov/forum/

Harmer, J. (1982). What is communicative? ELT Journal, 36(3), 164-168. https://doi.org/10.1093/elt/36.3.164

Kumaravadivelu, B. (2003). Beyond methods. London: Yale University Press.

Littlewood, W. (1981). Communicative language teaching: An introduction. Cambridge: Cambridge University Press.

Littlewood, W. (1984).Foreign and second language learning. Cambridge: Cambridge University Press.

Melvin, B. S., \& Stout, D. S. (1987).Motivating language learners through authentic materials. Interactive language teaching (pp. 44-56).

Murray, D. E., \& Christison, M. A. (2010). What English Language Teachers Need to Know: Understanding Learning. Abingdon: Taylor \& Francis.

Nakatani, Y. (2010). Identifying strategies that facilitate EFL learners' oral communication: A classroom study using multiple data collection procedures. The Modern Language Journal, 94(1), 346-512. https://doi.org/10.1111/j.1540-4781.2009.00987.x

Norton, B. (1995). Social Identity, Investment, and Language Learning. TESOL Quarterly, 29, 9-31. https://doi.org/10.2307/3587803

Norton, B. (1997). Language, Identity, and the Ownership of English. TESOL Quarterly, 31, 409-429. https://doi.org/10.2307/3587831

Norton, B., \& Toohey, K. (2001). Changing Perspectives on Good Language Learners. TESOL Quarterly, 35, 307-332. https://doi.org/10.2307/3587650

Palmer, B. C., El-Ashry, F., Leclere, J. T., \& Chang, S. (2007). Learning from Abdallah: A Case study of an Arabic-speaking child in a U.S. school. The Reading Teacher, 61(1), 817. https://doi.org/10.1598/RT.61.1.2

Rabab'ah, G. (2005). Communication problems facing Arab learners of English. Journal of Language and Learning, 3(1).

Santos, S., \& Suleiman, M. (1993). Teaching English to Arabic-speaking students: cultural and linguistic considerations. Proceedings of the National Annual Association for Bilingual Education Conferences, Washington.

Scrivener, J. (1994). Learning teaching. London: Macmillan Publishers Limited.

Ur, P. (1996). A course in language teaching. Cambridge: Cambridge University Press.

Willis, J. (1996). A frame work for task- based learning. Harlow: Pearson Education Limited.

Wingfield, M., \& Karaman, B. (2001). Arab stereotypes and American educators. Retrieved from the website of the American-Arab Antidiscrimination Committee.

Zhang, S. (2009).The role of input, interaction, and output in the development of oral fluency. English Language Teaching, 2(4), 91-100. https://doi.org/10.5539/elt.v2n4p91

\section{Copyrights}

Copyright for this article is retained by the author(s), with first publication rights granted to the journal.

This is an open-access article distributed under the terms and conditions of the Creative Commons Attribution license (http://creativecommons.org/licenses/by/4.0/). 